\title{
The Dual Roles of Zinc Sulfate in Mitigating Peach Gummosis
}

\author{
Zhi Li, Yanchun Fan, Lei Gao, Xiu Cao, Junli Ye, and Guohuai Li, Key Laboratory of Horticultural Plant Biology, Huazhong Agricultural
} University, Ministry of Education, Wuhan, 430070, China

\begin{abstract}
Li, Z., Fan, Y., Gao, L., Cao, X., Ye, J., and Li, G. 2016. The dual roles of zinc sulfate in mitigating peach gummosis. Plant Dis. 100:345-351.

Peach gummosis, caused by Lasiodiplodia theobromae, is one of the most prevalent diseases that affects peach production. In this study, we investigated the effect of zinc sulfate on inoculated peach shoots, as well as on the growth, morphology, and pathogenicity of L. theobromae in vitro, in the laboratory. Zinc deficiency was detected in diseased peach shoots by micronutrient analysis $(\mathrm{Cu}, \mathrm{Mn}$, and $\mathrm{Zn})$ and confirmed by the measurement of transcript levels of zinc transporters (ZIP4, HAM4, and $Z A T)$. The zinc was transferred from the diseased peach shoots to the peach gum. Applying zinc sulfate to the diseased peach shoots reduced the severity of peach gummosis, showing significantly reduced lesion size and gum weight, as well as downregulation of cell wall

degradation-related gene ( $P G$ and $P M E$ ) compared with the control. Zinc sulfate also specifically controlled peach gummosis under $L$. theobromae phytotoxin stress and induced the expression of defense-related genes (PR4, CHI, PAL, PGIP, and GNS3). In addition, in vitro mycelial growth of $L$. theobromae was significantly inhibited by zinc sulfate compared with the control. Zinc sulfate caused abnormal hyphae at $25 \mathrm{mM}$ and swelling hyphal tips at $50 \mathrm{mM}$. Exposure of $L$. theobromae to zinc sulfate for 20 min inhibited the ability of the pathogen to cause peach gummosis. Our physiological and molecular data demonstrated that zinc sulfate has a dual function by reducing susceptibility in the host and by direct inhibition of the pathogen.
\end{abstract}

Peach gummosis is one of the most prevalent and damaging peach diseases in China, Japan, and the United States (Reilly and Okie 1982; Wang et al. 2011). Lasiodiplodia theobromae causes disease on a number of hosts including gummosis in peach and apricot (Li et al. 1995), canker disease in grapevine (Urbez-Torres et al. 2008), fruit rot disease in banana (Mortuza and Ilag 1999), inflorescence blight in mango (Serrato-Diaz et al. 2013), and black branch dieback in cashew (Cardoso et al. 2002). The common symptoms of peach gummosis include necrotic lesions on the bark and gum formation on the trunks, branches, and fruits (Biggs and Britton 1988). The occurrence of this disease results in earlier defoliation, twig die back, reduced vigor, and decreased fruit production (Li et al. 1995).

Historically, chemical control has been used widely used to suppress plant diseases caused by L. theobromae. For peach gummosis, disease severity significantly decreased after treatment with captafol on susceptible peach cultivars (Beckman et al. 2003). In mango, 2,4-dichlorophenoxyacetic acid (2,4-D) reduced the incidence of stem end rot of fruit caused by L. theobromae (Kobiler et al. 2001). Bester et al. (2007) observed that fenarimol was effective fungicide against $L$. theobromae. In Japan, gummosis of apricot caused by L. theobromae was reportedly suppressed by the application of thiophanate-methyl (Li et al. 1995). In contrast to fungicides, pretreatment of banana fruits with Trichoderma viride effectively controlled storage rots caused by L. theobromae (Mortuza and Ilag 1999).

The effect of micronutrients on reducing the severity of diseases can be attributed to their involvement in physiology, and the expression of disease resistance in the plant (Dordas 2008). Reduction in disease severity has been reported in cucumber plants after foliar application of $\mathrm{CuSO}_{4}$, which provided protection against powdery mildew (Reuveni et al. 1997). Mn has an important role in lignin biosynthesis, phenol biosynthesis, and photosynthesis. Mn fertilization can also suppress a number of pathogenic diseases, such as

\section{Corresponding author: Guohuai Li, E-mail: liguohuai@mail.hzau.edu.cn}

* The $\boldsymbol{e}$-Xtra logo stands for "electronic extra" and indicates that one supplementary figure is published online.

Accepted for publication 22 May 2015.

http://dx.doi.org/10.1094/PDIS-01-15-0131-RE

C 2016 The American Phytopathological Society downy mildew, powdery mildew, and potato scab (Graham and Webb 1991; Simoglou and Dordas 2006). Fe is a component of peroxidase, which stimulates other enzymes involved in the biosynthetic pathway. Previous studies have shown that iron deficiency contributes to Arabidopsis thaliana soft rot disease symptoms (Kieu et al. 2012). $\mathrm{Zn}$ is also an essential micronutrient for plant growth and a catalytic component of over 300 enzymes belonging to six major enzyme classes, including hydrolases, transferases, oxidoreductases, lyases, ligases, and isomerases (Broadley et al. 2007; Grotz et al. 1998). Zinc has shown various effects on plant susceptibility to disease including both suppression and enhancement of the host pathogen interaction (Graham and Webb 1991; Grewal et al. 1996). Several genes are involved in zinc transport within plants. HMA4 is a ATPase that transports $\mathrm{Zn}$ and $\mathrm{Cd}$; a ZIP4 is expressed in shoots in response to $\mathrm{Zn}$ deficiency (Grotz et al. 1998; Verret et al. 2004), and ZAT is a Zn efflux gene that belongs to a cation diffusion facilitator family (Guerinot and Eidet 1999).

The current study aims to (1) evaluate the effects of zinc sulfate on the development of peach gummosis; (2) investigate the antifungal effects of Zn on mycelial growth, hyphal morphology, and pathogenicity of L. theobromae; and (3) observe the potential control of peach gummosis by zinc sulfate treatments.

\section{Materials and Methods}

Plant and fungus materials. Approximately 900 three-year-old peach trees with low incidence of peach gummosis were cultivated in an experimental field at Huazhong Agricultural University in Wuhan. No symptom was observed on the current-year peach shoots. For all inoculation experiments, current-year shoots were randomly collected from 120 plants of Prunus persica (L.) 'Springsnow' from June 2012 to August 2013. The plants were grafted on wild peach rootstock. L. theobromae strain JMB-122 was originally isolated from diseased peach orchards in Hubei Province, China (Wang et al. 2011) and stored on dry filter paper at $-20^{\circ} \mathrm{C}$.

Host inoculation and measurement of mineral content. The inoculation procedure was performed according to the method of $\mathrm{Li}$ et al. (2014a). Current-year peach shoots were surface sterilized with $70 \%$ alcohol for $10 \mathrm{~s}$, rinsed three times with sterile water, and cut into $15 \mathrm{~cm}$ length segments. The shoot segments were wounded with a sterilized needle, and an actively growing isolate of strain JMB-122 on a mycelial agar plug ( $4 \mathrm{~mm}$ in diameter) was placed over the

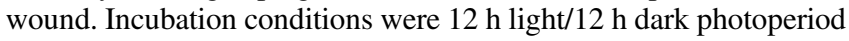
at $26^{\circ} \mathrm{C}$ with $90 \%$ relative humidity. For mineral analysis, host tissue 
samples were collected from 10 inoculated peach shoots and 10 non-inoculated shoots. Collected tissues included epidermal cells, phloem, and parenchyma (excluding xylem) and located within 0.5 to $1.0 \mathrm{~cm}$ of a lesion. Non-inoculated shoots were inoculated with sterile PDA plugs as control. Peach gum was also obtained from 10 diseased peach shoots at 3,4 , and 5 days post-inoculation (dpi). Three independent replicates were performed on the inoculated and control shoots. Each replicate comprised 10 current-year shoots.
To measure the mineral content of the shoot and gum samples, $0.5 \mathrm{~g}$ fresh host shoot tissue and gum samples were ground with liquid nitrogen and placed in a porcelain crucible. The furnace temperature was gradually increased from room temperature to $500^{\circ} \mathrm{C}$ within $30 \mathrm{~min}$ (Tüzen 2003). The samples were burned for approximately $8 \mathrm{~h}$ until a white ash residue was obtained. The residue was dissolved in $5 \mathrm{ml}$ of $1 \mathrm{M}$ hydrochloric acid. The levels of $\mathrm{Cu}$, $\mathrm{Mn}$, and $\mathrm{Zn}$ were determined by an atomic absorption spectrometer

Table 1. Gene-specific primer sequences of peach used in this study

\begin{tabular}{|c|c|c|c|c|c|}
\hline $\begin{array}{l}\text { Gene } \\
\text { name }\end{array}$ & $\begin{array}{l}\text { Accession } \\
\text { number }\end{array}$ & Forward primer $\left(5^{\prime}-3^{\prime}\right)$ & Reverse primer $\left(5^{\prime}-3^{\prime}\right)$ & $\begin{array}{l}\text { Amplicon } \\
\text { (bp) }\end{array}$ & Description \\
\hline$\overline{\mathrm{CHI}}$ & DY641594x & TTCTGATTTCGGTCGGTTCG & GCTGTTTCCAGCAGCTCCAT & 232 & Chitinase IV \\
\hline GNS3 & $\mathrm{AF} 435089^{\mathrm{x}}$ & TCAAGCCCTCAGACTCCTATGC & AACGGCGATCTGTTGTTCACTA & 217 & Beta-1,3-glucanase 3 \\
\hline$P A L$ & AF206634x & AGCTTCACCCCTCTAGGTTCTGT & AGCCTGGCACTTTCAACTTCTTT & 253 & Phenylalanine ammonia lyase \\
\hline$P G$ & DQ340809x & AATGCCGCAGACCTAACCTACA & CCCGTTCACATGCTCAAACAAG & 288 & Endo-polygalacturonase \\
\hline$P G I P$ & EF409977x & GGGGCTGACCCAAGTGGATTT & AGCCTGTCTAGCACTGGTGGC & 256 & $\begin{array}{l}\text { Polygalacturonase-inhibiting } \\
\text { protein }\end{array}$ \\
\hline$P M E$ & $\mathrm{AB} 231903^{x}$ & CCTCAGTCAACTCCACACCCAC & AGTCACCATTCCACTCAAGCCA & 126 & Pectin Methylesterase 1 \\
\hline PR4 & AF362989x & GGTGACAAACACGGGCACAGGAG & AAGAAGCGATCCCACTTTGAACT & 251 & Pathogenesis-related protein 4 \\
\hline HMA4 & ppa000656m $\mathrm{m}^{\mathrm{y}}$ & TTGAAGGTCGTAAGGGTGGG & TGCTGCGGCATGACTATCTC & 173 & $\begin{array}{l}\text { Cadmium/zinc-transporting } \\
\text { ATPase }\end{array}$ \\
\hline ZAT & ppa006401m $\mathrm{m}^{\mathrm{y}}$ & AAGCCTGAGTGGAAGATAGTCGA & CACTTCATCCATCTCCAGCAAC & 171 & Zinc transporter \\
\hline ZIP4 & ppa006989m $m^{y}$ & TGCCACGTTGCTCGTTGACT & CCTTCCCATTCCGATCCTTTT & 158 & Zinc transporter 4 \\
\hline$T E F 2^{\mathrm{z}}$ & JQ732180x & AGCAAGTCACCCAACAAGCATA & CCAACCAAACTCTTCAGCCAAT & 147 & Translation elongation factor 2 \\
\hline
\end{tabular}

$\mathrm{x}$ Accession number from GenBank.

y Sequence from peach genome database at phytozome (http://www.phytozome.net/peach.php).

z Peach housekeeping normalization gene.

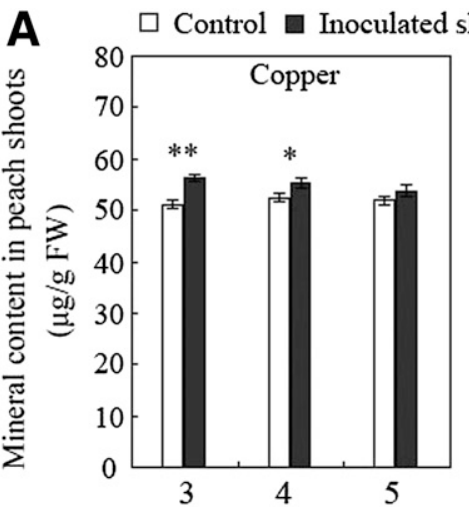

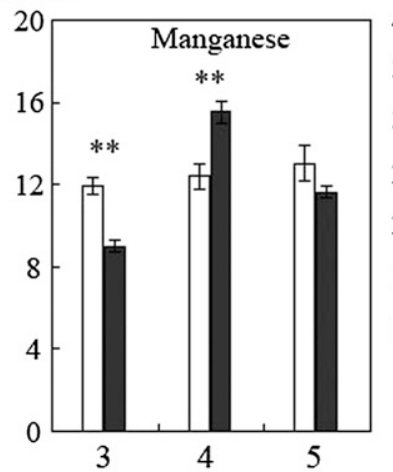

Time after inoculation (dpi)

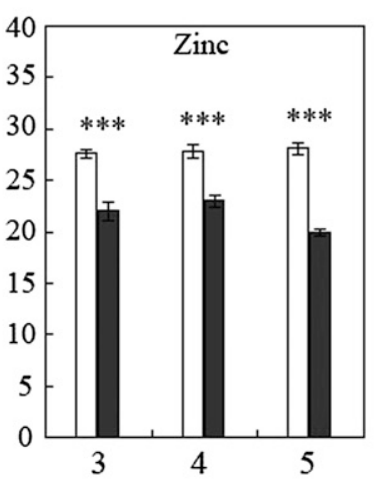

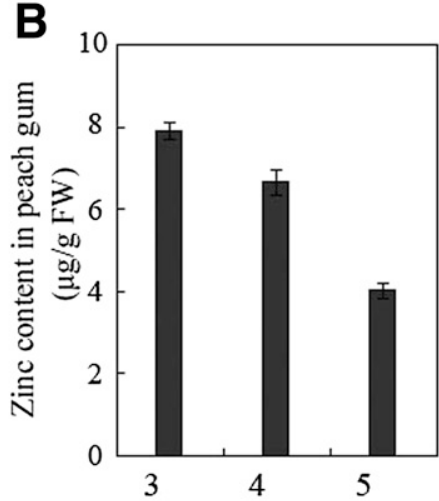

Time after inoculation (dpi)
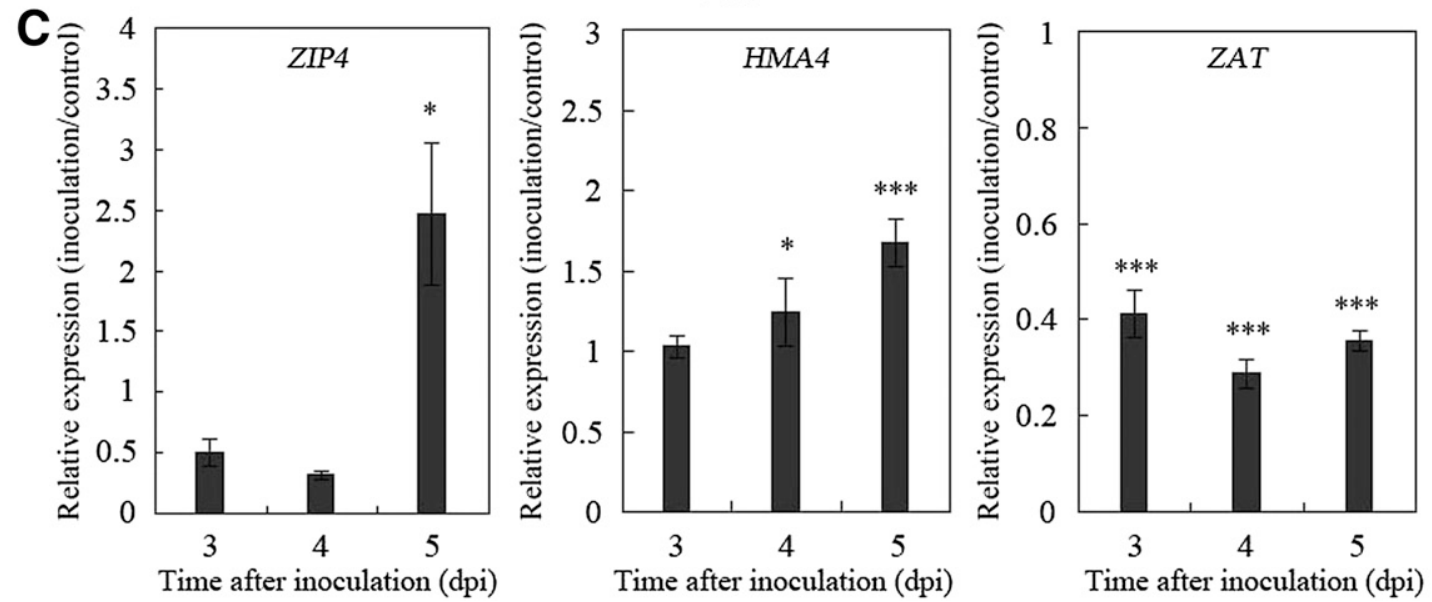

Fig. 1. Level of micronutrients in peach infected shoots compared with the control shoots and the relative expression of Zn-transporter genes after inoculation with Lasiodiplodia theobromae. A, Levels of $\mathrm{Cu}, \mathrm{Mu}$, and $\mathrm{Zn}$ in diseased and control shoots of peach. B, $\mathrm{Zn}$ content in peach gum at 3, 4, and 5 days post-inoculation. C, Expression levels of zinc transporter 4 (ZIP4), cadmium/zinc-transporting ATPase (HMA4), and zinc transporter (ZAT) in comparison with that of peach TEF2 were determined by qRT-PCR. Significant differences in relative transcript levels between inoculated and control shoots were estimated by performing Student's $t$ test on individual ${ }^{\triangle} \mathrm{CT}$ values (Yuan et al. 2006). Data and relative values are the means $\pm \mathrm{SD}$ of three biological replicates. Asterisks indicate a significant difference $\left({ }^{*} P<0.05,{ }^{* \star} P<0.01\right.$, and $\left.{ }^{* * *} P<0.001\right)$. 
(Spectr AA 220, Varian, Palo Alto, CA). Mineral content was expressed as $\mu \mathrm{g} / \mathrm{g}$ fresh weight. The relative expression of ZIP4, $H M A 4$, and ZAT was analyzed by quantitative real time (qRT)PCR to investigate zinc transport during the development of peach gummosis (see below and Table 1).

Application of $\mathrm{Zn}$ sulfate solution on peach inoculated shoots. Strain JMB-122 was cultured on potato dextrose agar (PDA) media for 3 days prior to inoculation. Current-year peach shoots were inoculated with $L$. theobromae strain JMB-122. The inoculation procedure also was executed as described by Li et al. (2014a). For Zn sulfate treatments, the inoculated peach shoots were treated with $10 \mathrm{ml}$ of $\mathrm{Zn}$ sulfate solution at concentrations of either 25 and $50 \mathrm{mM}$ for $24 \mathrm{~h}$ at $12 \mathrm{~h}$ intervals. Control shoots were sprayed only with sterile water. The treated and control shoots were then inoculated and incubated with a $12 \mathrm{~h}$ light/12 $\mathrm{h}$ dark photoperiod at $26^{\circ} \mathrm{C}$ with $90 \%$ relative humidity. Three independent replicates were performed on the inoculated and control shoots. Each replicate comprised 10 current-year shoots. Disease severity was evaluated by measuring the lesion diameter and gum weight at 1,2,3, and 4 dpi. Tissue samples $(0.5 \mathrm{~g})$ for cell wall degradation-related gene ( $P G$ and $P M E$ ) expression analysis by qRT-PCR were collected in the proximity of the inoculation sites as described above, frozen in liquid nitrogen, and stored at $-80^{\circ} \mathrm{C}$ (see below and Table 1).

Collection of phytotoxins produced by $L$. theobromae. L. theobromae strain JMB-122 was grown on PDA medium at $26^{\circ} \mathrm{C}$ for 3 days according to the methods of Abdou et al. (2010). For phytotoxin production, six 4-mm mycelial plugs from PDA cultures were placed in a 500-ml flask containing $200 \mathrm{ml}$ of modified Richard's liquid medium (3\% sucrose, $1 \% \mathrm{KNO}_{3}, 0.5 \% \quad \mathrm{KH}_{2} \mathrm{PO}_{4}, 0.25 \%$ $\mathrm{MgSO}_{4}$ ). The cultures were then incubated at $26^{\circ} \mathrm{C}$ in a water bath
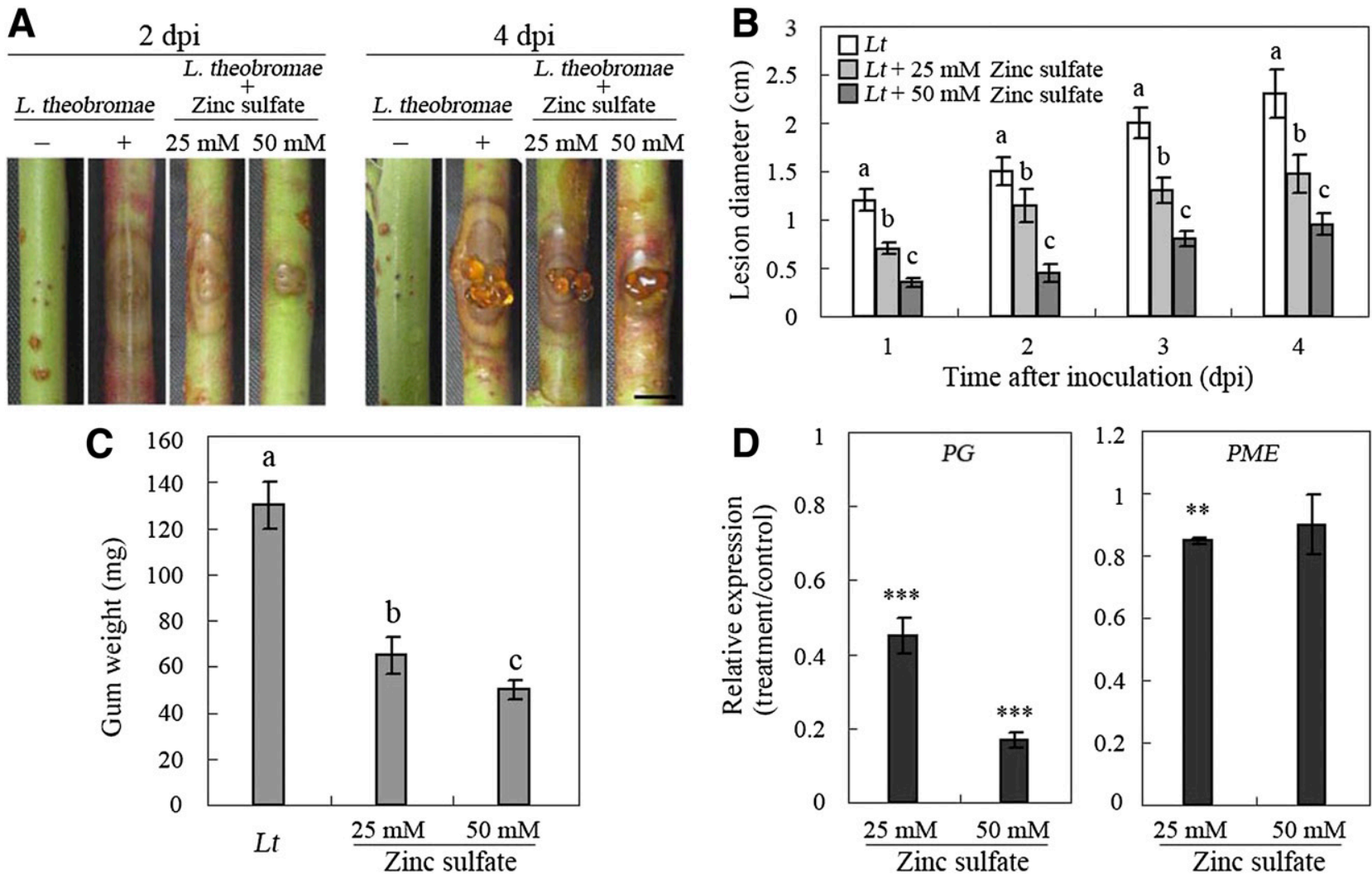

Fig. 2. Effect of zinc sulfate treatments on the symptoms of peach gummosis and transcript level of cell wall degradation related-genes. A, Symptoms of gummosis in peach shoots with or without Lasiodiplodia theobromae and inoculated shoots after applying zinc sulfate at 2 and 4 days post-inoculation (dpi). Bar, $5 \mathrm{~mm}$. B, Lesion diameter on untreated inoculated shoots and inoculated shoots with zinc sulfate $(25$ and $50 \mathrm{mM})$ treatment. Relative values are the means $\pm S D$ of three biological replicates. For each time point, bars with different letters are significantly different $(P<0.05)$. C, Gum weight harvested from diseased shoots at 4 dpi. Bars with different letters are significantly different $(P<0.05)$. D, The transcripts level of endo-polygalacturonase $(P G)$ and pectin methylesterase $(P M E)$ in inoculated shoots at 3 dpi. Significant differences in relative transcript levels between inoculated shoots with zinc sulfate $(25$ and $50 \mathrm{mM})$ treatment and untreated inoculated shoots were estimated by Student's $t$ test on individual ${ }^{\Delta} \mathrm{CT}$ values (Yuan et al. 2006). Data and relative values are the means $\pm \mathrm{SD}$ of three biological replicates. Asterisks indicate a significant difference $\left({ }^{* \star} P<0.01\right.$ and $\left.{ }^{* \star *} P<0.001\right)$.

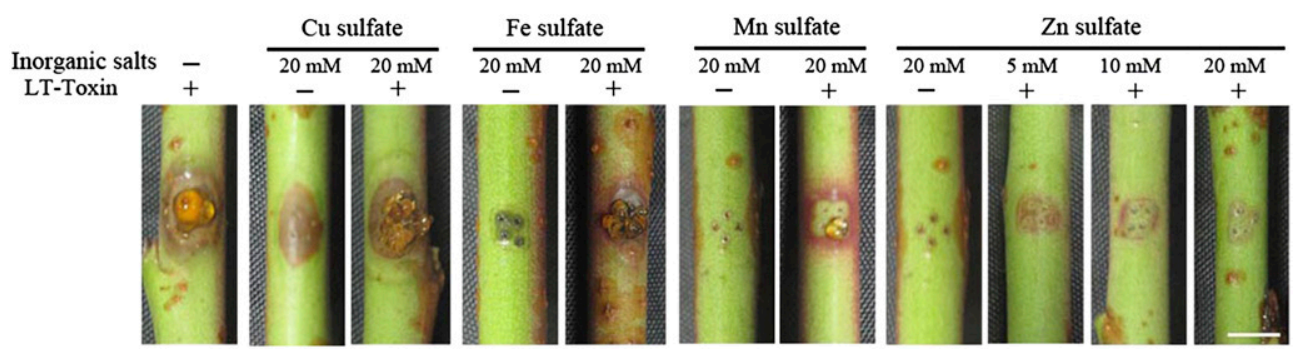

Fig. 3. Symptoms of gummosis in peach shoots after inoculation with Lasiodiplodia theobromae phytotoxins (LT-toxin) and the combination of phytotoxins and Cu sulfate, Fe sulfate, $\mathrm{Mn}$ sulfate, and $\mathrm{Zn}$ sulfate at 4 days post-inoculation. Scale bar, $5 \mathrm{~mm}$. 
shaker (70 rpm) for 21 days. Extraction assay was conducted according to the methods of Singh et al. (2010) with minor modifications. Approximately $800 \mathrm{ml}$ of culture filtrate was extracted three times with half volumes of ethyl acetate using a separatory funnel. Organic solvent fractions were evaporated to dryness at $55^{\circ} \mathrm{C}$. After weighing, the residues were dissolved in $5 \mathrm{ml}$ sterile distilled water and adjusted to a concentration of $100 \mu \mathrm{g} / \mathrm{ml}$ phytotoxin.

Effect of micronutrients on peach gummosis caused by $L$. theobromae phytotoxin. To determine the effect of micronutrients on peach gummosis, we tested the toxicity of $L$. theobromae phytotoxin amended with sulfate salts of $\mathrm{Cu}, \mathrm{Fe}, \mathrm{Mn}$, or $\mathrm{Zn}$. Mineral salts were dissolved in sterile distilled water and filtered through a $0.22 \mu \mathrm{m}$ filter. Wounds on shoots were inoculated with $6 \mu \mathrm{l}$ of a mixture of mineral salts and phytotoxin at a ratio of 1:5 (v/v). The tested concentrations of $\mathrm{Zn}$ sulfate were 5, 10, and $20 \mathrm{mM}$; $\mathrm{Cu}$ sulfate, $\mathrm{Fe}$ sulfate, and Mn sulfate were tested at $20 \mathrm{mM}$. Phytotoxin without mineral salt was the control.

The peach shoots were cut into $15-\mathrm{cm}$ segments for the inoculation assay. These segments were surface sterilized with $70 \%$ ethanol for $10 \mathrm{~s}$, rinsed three times with sterile water, and wounded at the middle with a sterilized needle. Approximately $6 \mu l$ of the phytotoxin/mineral solution was inoculated on the wounded sites. After drying of the phytotoxin treatment, sterile water was sprayed on the shoots to maintain humidity at $12 \mathrm{~h}$ interval. The shoots were placed in plastic boxes, covered with a clear plastic film, and incubated in a chamber at $26^{\circ} \mathrm{C}$ under a $12 \mathrm{~h} / 12 \mathrm{~h}$ light/dark photoperiod. The inoculated and control shoots each had three independent replicates. Each replicate comprised 10 current-year shoots. As described above, tissue samples were collected from within a 0.5 to $1.0 \mathrm{~cm}$ from a lesion at $12,24,48$, and $72 \mathrm{~h}$ postinoculation (hpi), frozen in liquid nitrogen, and stored at $-80^{\circ} \mathrm{C}$ for defense-related gene (PR4, CHI, PAL, PGIP, and GNS3) expression analysis by qRT-PCR (see below and Table 1).

Effect of $\mathrm{Zn}$ sulfate on $L$. theobromae growth, morphology, and pathogenicity. Active mycelia of $L$. theobromae strain JMB122 were transferred to plates of PDA amended with $0,5,10,25$, and $50 \mathrm{mM} \mathrm{Zn}$ sulfate. Inoculation assays were performed with three biological replicates; each replicate comprised three plates. The plates were incubated at $26^{\circ} \mathrm{C}$ with a $12 \mathrm{~h} / 12 \mathrm{~h}$ light/dark photoperiod. Colony diameter of $L$. theobromae strain JMB-122 was recorded and observed from 1 to 5 dpi. To observe the hyphal morphology, three plates were selected from Zn-treated and control cultures of L. theobromae strain JMB-122. In each plate, three hyphae were randomly selected and observed. The hyphae were sampled from the edge of the colony using a sterile inoculation needle and subsequently placed on slides. The specimens were observed using an Eclipse 90i microscope (Nikon, Tokyo, Japan) under bright-field light at $40 \times$ magnification. For the infectivity assay, strain JMB122 was grown on a PDA medium at $26^{\circ} \mathrm{C}$ for 3 days. Mycelial plugs ( $4 \mathrm{~mm}$ in diameter) from PDA cultures were placed in a $1.5 \mathrm{ml}$ tube containing different $\mathrm{Zn}$ sulfate concentrations $(10,25$, and $50 \mathrm{mM})$ for $20 \mathrm{~min}$. The plugs were subsequently inoculated on wounded peach shoots. Inoculation procedure was performed as described above (Li et al. 2014a).

RNA extraction and qRT-PCR for gene expression. For collected peach tissue samples, total RNA was extracted from $0.5 \mathrm{~g}$ of frozen current-year shoot tissues using an EASYspin Plus RNA kit
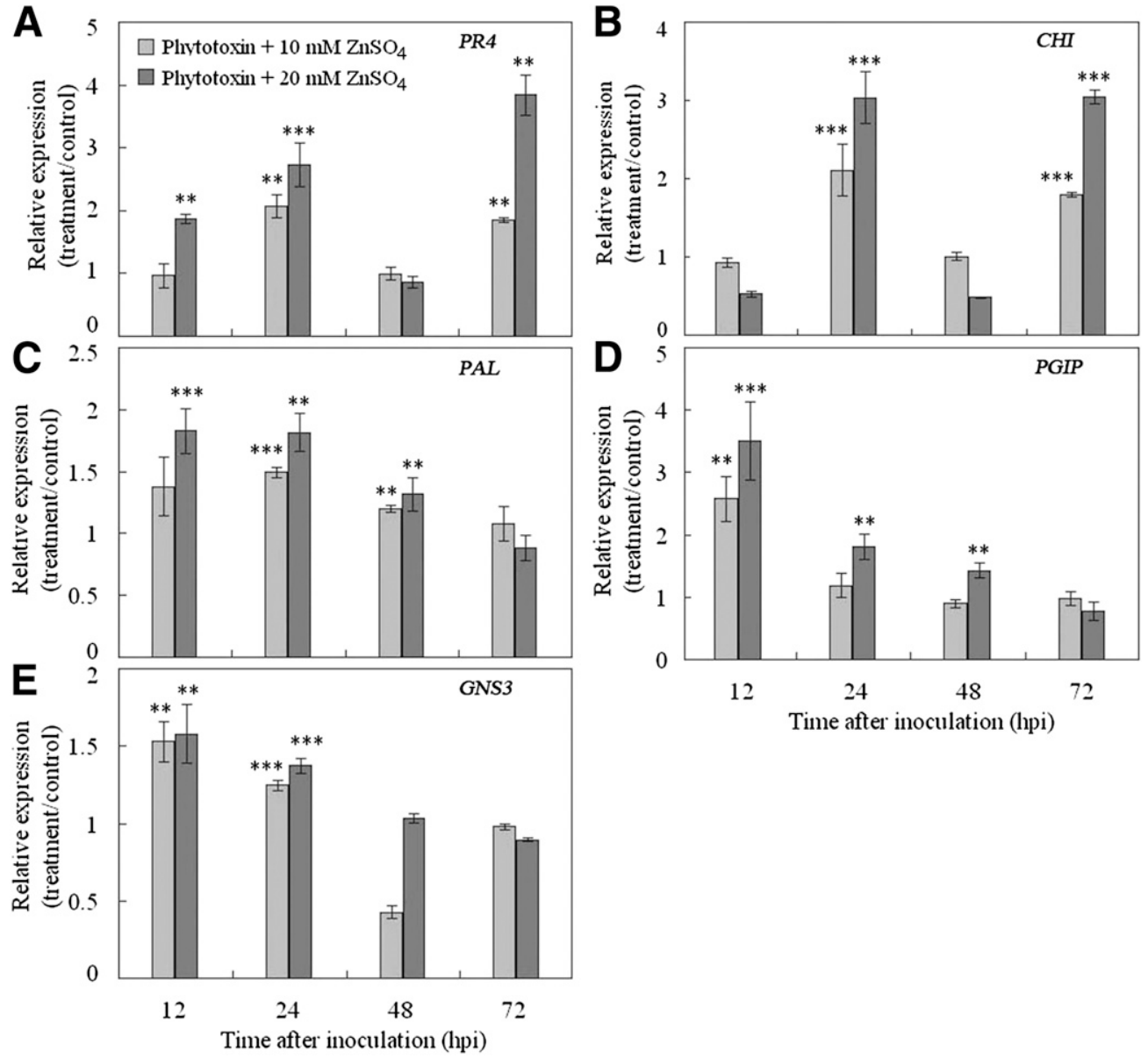

Fig. 4. Effects of Zn sulfate on the expression of defense-associated genes of peach (A, PR4; B, CHI; C, PAL; D, PGIP; E, GNS3). The transcripts level of defense-related genes between 12 and $72 \mathrm{~h}$ post-inoculation in peach shoots inoculated with phytotoxins of Lasiodiplodia theobromae with or without $\mathrm{Zn}$ sulfate. Significant differences in relative transcript levels between shoots inoculated with phytotoxins amended with Zn sulfate (10 and $20 \mathrm{mM}$ ) and phytotoxin alone were estimated by Student's $t$ test on individual ${ }^{\Delta} \mathrm{CT}$ values (Yuan et al. 2006). Relative values are the means $\pm S D$ of three biological replicates. Asterisks indicate a significant difference $\left({ }^{* *} P<0.01\right.$ and $\left.{ }^{* * *} P<0.001\right)$. 
(Aidlab, Beijing, China). DNase I (TaKaRa, Dalian, China) was added to remove genomic DNA. RNA yield and purity were analyzed with NanoDrop 2000 (Thermo, Wilmington, DE), and RNA integrity was measured by electrophoresis in $1.5 \%$ agarose gel. First-strand cDNA was synthesized from total RNA with oligo(dT) primers according to the instructions on the PrimeScript RT reagent kit (TaKaRa, Dalian, China).

qRT-PCR was performed in a LightCycler 480 Sequence Detection System (Roche, Basel, Switzerland) with intercalation dye SYBR Green as the fluorescent reporter. Reactions were conducted at a final volume of $15 \mu \mathrm{l}$, with $30 \mathrm{ng}$ of cDNA, $10 \mu \mathrm{mol}$ of each primer, and $7.5 \mu l$ of $2 \times$ SYBR Green PCR master mixes (TaKaRa, Dalian, China), according to instructions of the manufacturer. PCR primers were designed based on the peach cDNA sequences published in the GenBank database and described in Table 1. Thermal cycling conditions comprised $2 \mathrm{~min}$ of denaturation at $95^{\circ} \mathrm{C}$, followed by 40 cycles of amplification $\left(95^{\circ} \mathrm{C}\right.$ for $15 \mathrm{~s}, 60^{\circ} \mathrm{C}$ for $15 \mathrm{~s}$, and $72^{\circ} \mathrm{C}$ for $30 \mathrm{~s}$ ). Translation elongation factor 2 (TEF2) of peach was used as reference, as proposed by a previous report (Tong et al. 2009). Relative expression levels were calculated by the ${ }^{\Delta \Delta} \mathrm{CT}$ method (Livak and Schmittgen 2001). qRT-PCR results were expressed as mean \pm SD of three independent biological replicates.

Statistical analysis. Student's $t$ tests were used for statistical analysis of the content of elements and gene relative expression level. For the suppression assay, colony diameter and lesion diameter were compared with multiple comparison tests. Statistically significant differences were assessed by testing for least significant difference $(P<0.05)$.

\section{Results}

Zn deficiency in diseased peach shoots. The $\mathrm{Zn}$ content was significantly lower $(P<0.01)$ in inoculated peach shoot tissues than the control shoots. Similarly, the Mn level was only lower than control shoots at 3 dpi. In contrast, the $\mathrm{Cu}$ level significantly increased in the inoculated shoots at 3 and 4 dpi (Fig. 1A). Zinc was detected in the peach gum (Fig. 1B). To investigate the regulatory mechanism underlying the effect of $\mathrm{Zn}$ content in the host tissue, we examined the transcript abundance of ZIP4, HMA4, and ZAT in the control and diseased peach shoots. The transcript levels of ZIP4 and HMA4 were significantly increased in diseased shoots compared with the control shoots at $5 \mathrm{dpi}$. Conversely, ZAT was significantly downregulated in diseased shoots compared with the control shoots at 3,4 , and 5 dpi (Fig. 1C).

Application of zinc sulfate alleviates the development of peach gummosis. In comparison with the control shoots, the $\mathrm{Zn}$ treated shoots displayed reduced symptoms of peach gummosis (Fig. 2A). Lesion diameters were smaller and gum weights were significantly $(P<0.05)$ reduced in shoots treated with 25 and $50 \mathrm{mM}$ zinc sulfate compared with control shoots (Figs. 2B and C). We did not observe evident changes in lesion diameter after application of copper sulfate and manganese sulfate compared with the control (Supplementary Fig. S1). The expression of endo-polygalacturonase

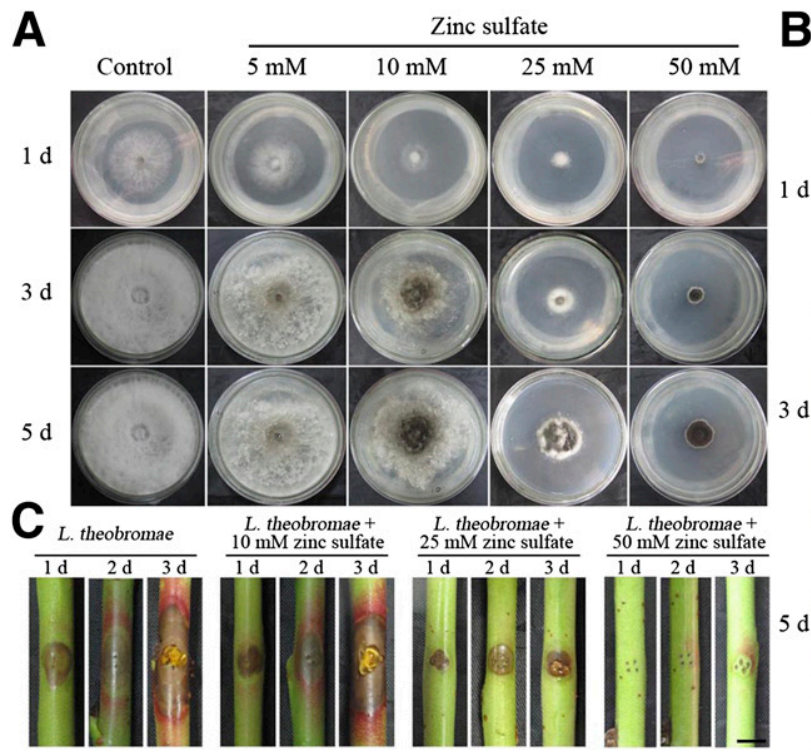

B

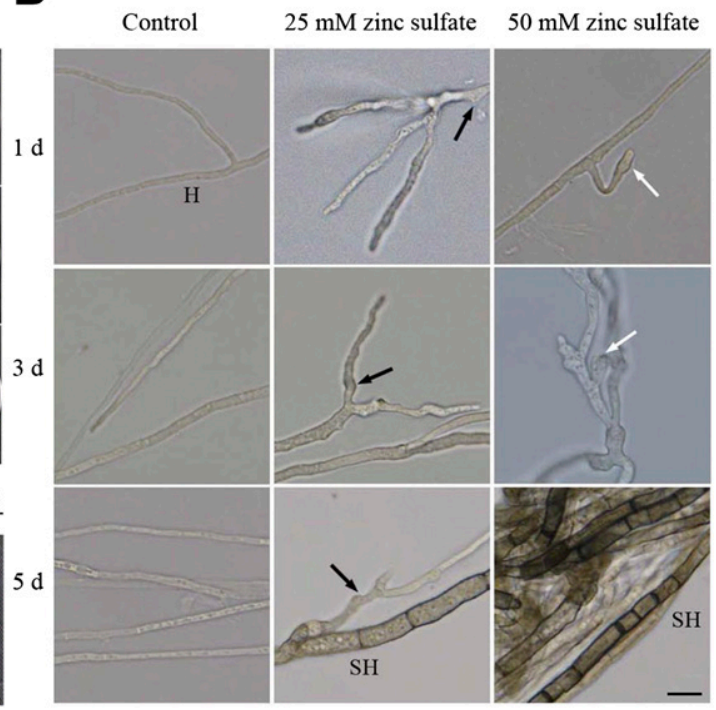

Fig. 5. Effects of zinc sulfate on mycelial growth, morphology, and pathogenicity of Lasiodiplodia theobromae on peach shoots. A, Mycelia cultured on potato dextrose agar with 0,5 , 10,25 , and $50 \mathrm{mM}$ zinc sulfate at $26^{\circ} \mathrm{C}$ for 1,3 , and 5 days. B, Effect of zinc sulfate on mycelial morphology of $L$. theobromae. Mycelia were cultured in PDA medium with $5,10,25$, and $50 \mathrm{mM}$ zinc sulfate or without zinc sulfate (control) at $26^{\circ} \mathrm{C}$ for 1,3 , and 5 days. $\mathrm{H}$, hypha; SH, septa hypha. Black arrows represent abnormal hyphae, and white arrows represent swelling hyphal tips. Scale bar $=10 \mu \mathrm{m}$. C, Effect of zinc sulfate treatment of $L$. theobromae plugs on the pathogen's ability to infect peach shoots. Mycelium plugs $(4 \mathrm{~mm})$ were treated with 10,25 , and $50 \mathrm{mM}$ zinc sulfate for $20 \mathrm{~min}$ or left untreated prior to inoculation on peach shoots. Scale bar $=5 \mathrm{~mm}$.

Table 2. Impact of zinc sulfate on colony diameter of Lasiodiplodia theobromae on PDA and lesion diameter of peach inoculated shoots by treated $L$. theobromae with zinc sulfate

\begin{tabular}{|c|c|c|c|c|c|c|}
\hline \multirow[b]{2}{*}{ Zinc sulfate Treatments } & \multicolumn{3}{|c|}{ Colony diameter $(\mathrm{cm})^{\mathrm{y}}$} & \multicolumn{3}{|c|}{ Lesion diameter $(\mathbf{c m})^{\mathrm{z}}$} \\
\hline & $1 \mathrm{~d}$ & $3 \mathrm{~d}$ & $5 \mathrm{~d}$ & $1 \mathrm{~d}$ & $2 \mathrm{~d}$ & $3 \mathrm{~d}$ \\
\hline $0 \mathrm{mM}$ & $4.36 \pm 0.15 \mathrm{a}$ & $9.00 \pm 0.00 \mathrm{a}$ & $9.00 \pm 0.00 \mathrm{a}$ & $0.77 \pm 0.04 \mathrm{a}$ & $1.03 \pm 0.08 \mathrm{a}$ & $1.98 \pm 0.15 \mathrm{a}$ \\
\hline $10 \mathrm{mM}$ & $2.32 \pm 0.11 b$ & $5.60 \pm 0.10 b$ & $7.93 \pm 0.21 b$ & $0.71 \pm 0.04 \mathrm{~b}$ & $0.95 \pm 0.05 \mathrm{a}$ & $1.71 \pm 0.10 \mathrm{~b}$ \\
\hline $25 \mathrm{mM}$ & $1.63 \pm 0.15 \mathrm{c}$ & $2.67 \pm 0.15 c$ & $3.45 \pm 0.22 c$ & $0.41 \pm 0.04 \mathrm{c}$ & $0.50 \pm 0.02 b$ & $0.53 \pm 0.08 \mathrm{c}$ \\
\hline $50 \mathrm{mM}$ & $0.60 \pm 0.05 \mathrm{~d}$ & $1.10 \pm 0.10 \mathrm{~d}$ & $2.17 \pm 0.15 d$ & $0.00 \pm 0.00 \mathrm{~d}$ & $0.00 \pm 0.00 \mathrm{c}$ & $0.00 \pm 0.00 \mathrm{~d}$ \\
\hline
\end{tabular}

${ }^{x}$ Mean values followed by different letters differ significantly within a row according to multiple comparison tests (least significant difference, $P<0.05$ ).

y Colony diameter of $L$. theobromae on PDA with zinc sulfate at different concentrations.

${ }^{\mathrm{z}}$ Lesion diameter on current-year peach after inoculation with $L$. theobromae, which was treated for 20 min with $0,10,25$, and $50 \mathrm{mM}$ zinc sulfate. 
$(P G)$ significantly decreased by 53 and $81 \%$ in the shoots treated with 25 and $50 \mathrm{mM}$ zinc sulfate, respectively, at $5 \mathrm{dpi}$. The expression of pectin methylesterase $(P M E)$ was also downregulated in $\mathrm{Zn}$ treated shoots at $25 \mathrm{mM}$ relative to the control (Fig. 2D).

Zn sulfate inhibits virulence of $L$. theobromae phytotoxin and induces defense gene expression. Peach current-year shoots exhibited symptoms resembling peach gummosis when treated with $L$. theobromae phytotoxin. In contrast, the addition of $\mathrm{Zn}$ sulfate to the phytotoxin inhibited expression of the gummosis symptom, and phytotoxin-induced lesions were significantly $(P<0.05)$ smaller as a resulted of the zinc amendment (Fig. 3).

To verify that $\mathrm{Zn}$ sulfate increased the resistance of peach shoots to the phytotoxin, the expressions of five defense-related genes were examined in peach shoots inoculated with the phytotoxin with or without $\mathrm{Zn}$ sulfate treatment. The expressions of $\mathrm{PR} 4$ and $\mathrm{CHI}$ were significantly upregulated in the shoots simultaneously treated with $\mathrm{Zn}$ sulfate and inoculated with phytotoxin at 24 and $72 \mathrm{hpi}$, but the expressions were downregulated at 48 hpi (Figs. $4 \mathrm{~A}$ and B). The expressions of $P A L$ and $P G I P$ in the treated shoots were significantly greater than that in the control shoots at 12, 24, and $48 \mathrm{hpi}$. The expression of GNS3 was significantly increased at 12 and 24 hpi. (Figs. 4C, D, and E).

Effects of zinc sulfate on mycelial growth, morphology, and pathogenicity of $L$. theobromae. Mycelial growth of $L$. theobromae was significantly $(P<0.05)$ inhibited by zinc sulfate at 25 and $50 \mathrm{mM}$; however, $50 \mathrm{mM}$ zinc sulfate did not completely inhibit mycelial growth (Fig. 5A). Compared with the control, at 3 dpi, colony diameter of $L$. theobromae on PDA amended with zinc sulfate at 25 or $50 \mathrm{mM}$ was reduced 3.37-fold and 8.18 -fold, respectively (Table 2). L. theobromae normally forms smooth, white filamentous hyphae. However, abnormal hyphae and swollen hyphal tips of L. theobromae were observed in PDA media supplemented with 25 and $50 \mathrm{mM}$ zinc sulfate (Fig. 5B). In contrast to the control, the black septate hyphae increased with increasing zinc sulfate concentrations. As shown in Figure 5C, treatments with 25 and $50 \mathrm{mM}$ zinc sulfate significantly inhibited the development of peach gummosis. Lesion diameter was significantly $(P<0.05)$ inhibited by $\mathrm{Zn}$ treatments at 10,25 , and $50 \mathrm{mM}$ (Table 2). Gum formation was observed at 3 dpi in the control, whereas peach gum production was controlled by $50 \mathrm{mM} \mathrm{Zn}$ treatment after inoculation with $L$. theobromae.

\section{Discussion}

In this study, $\mathrm{Zn}$ deficiency was shown to be an important factor in the expression of symptoms of peach gummosis. Bolle-Jones and Hilton (1956) also observed that $\mathrm{Zn}$ deficiency in Hevea brasiliensis increased disease severity after infection by Oidium spp. Our previous study found that $P G$ is a cell wall degrading enzyme that is produced in peach shoots during $L$. theobromae infection ( $\mathrm{Li}$ et al. 2014b). After treatment with zinc sulfate, however, the expression of cell wall degradation-related genes ( $P G$ and $P M E)$ significantly decreased in inoculated peach shoots. To compensate for pathogeninduced $\mathrm{Zn}$ deficiency in diseased shoots, we applied zinc sulfate solutions to peach shoots. Our data displayed that zinc sulfate alleviates the development of peach gummosis, reducing both lesion development and gum formation. One possible explanation for this result is that $\mathrm{Zn}$ is important in maintaining the integrity or stability of biological membranes (Graham and Webb 1991). In addition, Zn could be an essential component of finger proteins that are involved in the amelioration of biotic stresses (Guo et al. 2009).

$\mathrm{Zn}$ sulfate also inhibited the development of peach gummosis caused by the mycelia of $L$. theobromae that had been treated with $50 \mathrm{mM}$ zinc sulfate for $20 \mathrm{~min}$. Previous studies reported that $\mathrm{Zn}$ has antifungal activity against Pycnoporus cinnabarinus and Pleurotus ostreatus (Malachova et al. 2011), and that $\mathrm{Zn}$ represses the production of the phytotoxin fusaric acid, which is a Fusarium oxysporum virulence factor (Duffy and Defago 1997). In addition, in Botrytis cinerea, $\mathrm{Zn}$ stress resulted in a decrease in the production of numerous cell wall degrading enzymes (Cherrad et al. 2012). Therefore, the effects of zinc sulfate on hyphal morphology, development, and phytotoxin production of $L$. theobromae may contribute in alleviating symptoms of peach gummosis.
In this study, zinc sulfate significantly inhibited in vitro mycelial growth of $L$. theobromae and caused the formation of abnormal hyphae and swelling of hyphal tips. These findings are consistent with those in previous reports, which stated that $\mathrm{Zn}$ significantly reduced the fungal biomass of $F$. oxysporum and ericoid mycorrhizas (Duffy and Defago 1997; Lanfranco et al. 2002). Chitin is the main cell wall polysaccharide. The abnormal hyphal morphology in the presence of zinc could have caused chitin deposition, as reported by Lanfranco et al. (2002). The mode of action of $\mathrm{Zn}$ sulfate against fungal pathogens is not well understood; however, ions of $\mathrm{Zn}$ at $50 \mathrm{mM}$ reportedly destroy the internal hydrostatic pressure of the cell and inhibit elongation of the hyphal tip of L. theobromae (Lew 2011).

Phytotoxins of pathogens can be used as experimental models to investigate the host responses (Mase et al. 2013). In order to eliminate the effect of zinc on the pathogen, we used toxin of L. theobromae with zinc sulfate to understand the effect of zinc on peach shoots. Our data showed zinc sulfate induced the expression of defenserelated genes and inhibited expression of the gummosis symptom. Previous reports had found systemic acquired resistance may be involved in the suppression of plant diseases by micronutrients, such as B, Mn, and Cu (Reuveni et al. 1997, 2000). Zinc sulfate may have similar function based on the protection against $L$. theobromae.

This study suggests that zinc sulfate has a dual function, namely enhancing peach resistance and inhibiting the pathogen. Zinc sulfate mitigated peach gummosis disease caused by L. theobromae. Our results showed that $\mathrm{Zn}$ was detected in the peach gum after infection. Previous reports demonstrated that peach gum was only soluble in water at high temperatures (Simas et al. 2008). Therefore, it is difficult for the plant to remobilize the zinc in peach gum. Based on mineral measurements and the measured expression levels of $\mathrm{Zn}$ transporter genes, $L$. theobromae was apparently a contributing factor in loss of $\mathrm{Zn}$ from the diseased peach shoots during peach gummosis development. Consequently, the application of zinc to diseased orchards may serve as a potential method to compensate zinc loss and mitigate peach gummosis. For example, application of $\mathrm{Zn}$ to the soil reduced infections of Fusarium graminearum (Grewal et al. 1996). As described by Cripps et al. (1983), foliar application with $3 \mathrm{~g} /$ liter zinc sulfate on peach completely inhibited growth of Trametes versicolor and Stereum strigosazonatum. However, excessive zinc can result in toxicity symptoms that include reduced yields and stunted growth, although zinc toxicity in crops is far less common than $\mathrm{Zn}$ deficiency. Toxicity symptoms usually become visible at a range of 100 to $300 \mathrm{mg} \mathrm{Zn}$ per $1 \mathrm{~kg}$ of leaf dry weight for most crops (Broadley et al. 2007). Therefore, more tests are need in the field for peach gummosis, such as effective zinc concentration, zinc toxicity range, and application times, among others.

Overall, our study contributed to the understanding of the mechanisms underlying how zinc sulfate improves the defense of peach against $L$. theobromae and provided new insights into host responses mediated by Zn. Further study is necessary to confirm the effect of zinc sulfate on peach gummosis in the field.

\section{Acknowledgments}

This research was supported by the National Natural Science Foundation of China (grant no. 31272120 and 31471840) and China Agriculture Research System (grant no. CARS-31).

\section{Literature Cited}

Abdou, R., Scherlach, K., Dahse, H. M., Sattler, I., and Hertweck, C. 2010 Botryorhodines A-D, antifungal and cytotoxic depsidones from Botryosphaeria rhodina, an endophyte of the medicinal plant Bidens pilosa. Phytochemistry 71: 110-116.

Beckman, T. G., Pusey, P. L., and Bertrand, P. F. 2003. Impact of fungal gummosis on peach trees. HortScience 38:1141-1143.

Bester, W., Crous, P. W., and Fourie, P. H. 2007. Evaluation of fungicides as potential grapevine pruning wound protectants against Botryosphaeria species. Austral. Plant Pathol. 36:73-77.

Biggs, A. R., and Britton, K. O. 1988. Presymptom histopathology of peach trees inoculated with Botryosphaeria obtuse and B. dothidea. Phytopathology 78: 1109-1118.

Bolle-Jones, E. W., and Hilton, R. N. 1956. Zinc-Deficiency of Hevea brasiliensis as a predisposing factor to Oidium infection. Nature 177:619-620. 
Broadley, M. R., White, P. J., Hammond, J. P., Zelko, I., and Lux, A. 2007. Zinc in plants. New Phytol. 173:677-702.

Cardoso, J. E., Vidal, J. C., Santos, A. D., Freire, F. C. O., and Viana, F. M. P. 2002. First report of black branch dieback of cashew caused by Lasiodiplodia theobromae in Brazil. Plant Dis. 86:558.

Cherrad, S., Girard, V., Dieryckx, C., Gonçalves, I. R., Dupuy, J. W., Bonneu, M., Rascle, C., Job, C., Job, D., Vacher, S., and Poussereau, N. 2012. Proteomic analysis of proteins secreted by Botrytis cinerea in response to heavy metal toxicity. Metallomics 4:835-846.

Cripps, J. E. L., Doepel, R. F., and McLean, G. D. 1983. Canning peach decline in Western Australia. II. Methods of prevention. Crop Pasture Sci. 34: 517-526.

Dordas, C. 2008. Role of nutrients in controlling plant diseases in sustainable agriculture. a review. Agron. Sustain. Dev 28:33-46.

Duffy, B. K., and Defago, G. 1997. Zinc improves biocontrol of Fusarium crown and root rot of tomato by Pseudomonas fluorescens and represses the production of pathogen metabolites inhibitory to bacterial antibiotic biosynthesis. Phytopathology 87:1250-1257.

Graham, R. D., Webb, M. J. 1991. Micronutrients and disease resistance and tolerance in plants. Pages 329-370 in: Micronutrients in Agriculture, 2nd ed. J. J. Mortvedt, F. R. Cox, L. M. Schuman, and R. M. Welch, eds. Soil Science Society of America, Madison, WI.

Grewal, H. S., Graham, R. D., and Rengel, Z. 1996. Genotypic variation in zinc efficiency and resistance to crown rot disease (Fusarium graminearum Schw. Group 1) in wheat. Plant Soil 186:219-226.

Grotz, N., Fox, T., Connolly, E., Park, W., Guerinot, M. L., and Eide, D. 1998. Identification of a family of zinc transporter genes from Arabidopsis that respond to zinc deficiency. P. Natl. Acad. Sci 95:7220-7224.

Guerinot, M. L., and Eidet, D. 1999. Zeroing in on zinc uptake in yeast and plants. Curr. Opin. Plant Biol. 2:244-249.

Guo, Y. H., Yu, Y. P., Wang, D., Wu, C. A., Yang, G. D., Huang, J. G., and Zheng, C. C. 2009. GhZFP1, a novel CCCH-type zinc finger protein from cotton, enhances salt stress tolerance and fungal disease resistance in transgenic tobacco by interacting with GZIRD21A and GZIPR5. New Phytol. 183:62-75.

Kieu, N. P., Aznar, A., Segond, D., Rigault, M., Simond-Cote, E., Kunz, C., Soulie, M. C., Expert, D., and Dellagi, A. 2012. Iron deficiency affects plant defence responses and confers resistance to Dickeya dadantii and Botrytis cinerea. Mol. Plant Pathol. 13:816-827.

Kobiler, I., Shalom, Y., Roth, I., Akerman, M., Vinokur, Y., Fuchs, Y., and Prusky, D. 2001. Effect of 2, 4-dichlorophenoxyacetic acid on the incidence of side and stem end rots in mango fruits. Postharvest Biol. Technol. 23:23-32.

Lanfranco, L., Balsamo, R., Martino, E., Perotto, S., and Bonfante, P. 2002. Zinc ions alter morphology and chitin deposition in an ericoid fungus. Eur. J. Histochem. 46:341-350.

Lew, R. R. 2011. How does a hypha grow? The biophysics of pressurized growth in fungi. Nat. Rev. Microbiol. 9:509-518.

Li, H. Y., Cao, R. B., and Mu, Y. T. 1995. In vitro inhibition of Botryosphaeria dothidea and Lasiodiplodia theobromae, and chemical control of gummosis disease of Japanese apricot and peach trees in Zhejiang Province, China. Crop Prot. 14:187-191.

Li, Z., Gao, L., Wang, Y. T., Zhu, W., Ye, J. L., and Li, G. H. 2014a. Carbohydrate metabolism changes in Prunus persica gummosis infected with Lasiodiplodia theobromae. Phytopathology 104:445-452.
Li, Z., Wang, Y. T., Gao, L., Ye, J. L., and Li, G. H. 2014b. Biochemical changes and defense responses during the development of peach gummosis caused by Lasiodiplodia theobromae. Eur. J. Plant Pathol. 138:195-207.

Livak, K. J., and Schmittgen, T. D. 2001. Analysis of relative gene expression data using real-time quantitative PCR and the $2^{-\Delta \Delta \mathrm{CT}}$ method. Methods 25:402-408.

Malachova, K., Praus, P., Rybkova, Z., and Kozak, O. 2011. Antibacterial an antifungal activities of silver, copper and zinc montmorillonites. Appl. Clay Sci. 53:642-645.

Mase, K., Ishihama, N., Mori, H., Takahashi, H., Kaminaka, H., Kodama, M., and Yoshioka, H. 2013. Ethylene-responsive AP2/ERF transcription factor MACD1 participates in phytotoxin-triggered programmed cell death. Mol. Plant-Microbe Interact. 26:868-879.

Mortuza, M. G., and Ilag, L. L. 1999. Potential for biocontrol of Lasiodiplodia theobromae (Pat.) griff. \& maubl. in banana fruits by Trichoderma species. Biol. Control 15:235-240.

Reilly, C. C., and Okie, W. R. 1982. Distribution in the southeastern United States of peach tree fungal gummosis by Botryosphaeria dothidea. Plant Dis. 66:158-161.

Reuveni, M., Agapov, V., and Reuveni, R. 1997. A foliar spray of micronutrient solutions induces local and systemic protection against powdery mildew (Sphaerotheca fuliginea) in cucumber plants. Eur. J. Plant Pathol. 103:581-588.

Reuveni, R., Dor, G., Raviv, M., Reuveni, M., and Tuzun, S. 2000. Systemic resistance against Sphaerotheca fuliginea in cucumber plants exposed to phosphate in hydroponics system, and its control by foliar spray of monopotassium phosphate. Crop Prot. 19:355-361.

Serrato-Diaz, L. M., Perez-Cuevas, M., Rivera-Vargas, L. I., and French-Monar, R. D. 2013. First report of Lasiodiplodia theobromae causing inflorescence blight of mango. Plant Dis. 97:1380.

Simas, F. F., Gorin, P. A. J., Wagner, R., Sassaki, G. L., Bonkerner, A., and Lacomini, M. 2008. Comparison of structure of gum exudate polysaccharides from the trunk and fruit of the peach tree (Prunus persica). Carbohydr. Polym. 71:218-228.

Simoglou, K., and Dordas, C. 2006. Effect of foliar applied boron, manganese and zinc on tan spot in winter durum wheat. Crop Prot. 25:657-663.

Singh, J., Quereshi, S., Banerjee, N., and Pandey, A. K. 2010. Production and extraction of phytotoxins from Colletotrichum dematium FGCC\# 20 effective against Parthenium hysterophorus L. Braz. Arch. Biol. Techn 53:669-678.

Tong, Z., Gao, Z., Wang, F., Zhou, J., and Zhang, Z. 2009. Selection of reliable reference genes for gene expression studies in peach using real-time PCR. BMC Mol. Biol. 10: 71.

Tüzen, M. 2003. Determination of heavy metals in soil, mushroom and plant samples by atomic absorption spectrometry. Microchem. J. 74:289-297.

Úrbez-Torres, J. R., Leavitt, G. M., Guerrero, J. C., Guevara, J., and Gubler, W. D 2008. Identification and pathogenicity of Lasiodiplodia theobromae and Diplodia seriata, the causal agents of bot canker disease of grapevines in Mexico. Plant Dis. 92:519-529.

Verret, F., Gravot, A., Auroy, P., Leonhardt, N., David, P., Nussaume, L. Vavasseur, A., and Richaud, P. 2004. Overexpression of AtHMA4 enhances root-to-shoot translocation of zinc and cadmium and plant metal tolerance. FEBS Lett. 576:306-312.

Wang, F., Zhao, L., Li, G., Huang, J., and Hsiang, T. 2011. Identification and characterization of Botryosphaeria spp. causing gummosis of peach trees in Hubei province, central China. Plant Dis. 95:1378-1384.

Yuan, J. S., Reed, A., Chen, F., and Stewart, C. N., Jr. 2006. Statistical analysis of real-time PCR data. BMC Bioinformatics 7:85. 